\title{
Phenological relationships between two insect galls and their host plants: Aspidosperma australe and $A$. spruceanum (Apocynaceae)
}

\author{
Priscila Tolentino Campos ${ }^{1}$, Maria Cecília Dias Costa ${ }^{1}$, Rosy Mary dos Santos Isaias ${ }^{1}$, \\ Ana Sílvia Franco Pinheiro Moreira² ${ }^{2}$ Denis Coelho de Oliveira ${ }^{1}$ and José Pires de Lemos-Filho ${ }^{1,3}$
}

Recebido em 20/08/2009. Aceito em 1/06/2010

RESUMO - (Relações fenológicas entre duas galhas induzidas por insetos e suas plantas hospedeiras: Aspidosperma australe e A. spruceanum (Apocynaceae)). Embora a diversidade de galhas na região neotropical seja grande, poucos são os estudos fenológicos comparando a fenologia das espécies hospedeiras com aquela das galhas. O desenvolvimento de galhas geralmente requer alta sincronia fenológica entre os organismos associados. A relação entre a fenologia de duas galhas foliares induzidas por um Cecidomyiidae e Aspidosperma spruceanum Benth. ex Müell. Arg. e de uma espécie de Pseudophacopteron sp. e A. australe Müell. Arg. foram investigadas. $\mathrm{O}$ trabalho foi realizado em dez indivíduos de cada espécie em intervalos quinzenais, levando em consideração a percentagem de folhas galhadas. Durante um ano, foram observadas três fenofases distintas para as galhas foliares e quatro fenofases para a hospedeira. A maior percentagem de folhas galhadas em A. australe (80\%) ocorreu após o pico de brotação, com uma boa correlação entre a brotação e a indução de novas galhas. Em A. spruceanum, a percentagem de folhas galhadas foi sempre acima de $50 \%$, o que pode ser relacionado à contínua produção de folhas e indução das galhas nesta espécie. Em ambas as espécies, as galhas em desenvolvimento foram observadas durante todo o ano, indicando multivoltinismo. A capacidade de induzir galhas em tecidos jovens e maduros parece ser uma boa estratégia para a sobrevivência destes galhadores.

Palavras chaves: abundância de galhas, fenologia, interação inseto-planta, sincronismo

\begin{abstract}
Phenological relationships between two insect galls and their host plants: Aspidosperma australe and A. spruceanum (Apocynaceae)). Although gall diversity in the Neotropical region is immense, comparative studies on the phenology of host plants and their galls are scarce. Gall systems generally require high levels of phenological synchrony between the associated organisms. The relationships between the phenology of two leaf galls induced by an unidentified Cecidomyiidae in Aspidosperma spruceanum Benth. ex Müell. Arg. and by Pseudophacopteron sp. in A. australe Müell. Arg. were investigated. The investigation was performed on ten individuals per species in 15-day intervals taking into consideration the percentage of galled leaves. In a one-year study, three distinct phenophases for the leaf galls and four phenophases for host plants were observed. The maximum percentage of leaf galls $(80 \%)$ on $A$. australe occurred just after the peak of leaf sprouting. In $A$. spruceanum, the percentage of leaf galls was always over $50 \%$, which can be related to continuous leaf production and gall induction in this species. In both species, developing galls were observed over the entire year, indicating multivoltinism. The ability to induce galls at young and mature sites seems to be a good strategy for galling species survivorship.
\end{abstract}

Key words: gall abundance, plant interaction, phenology, synchronism

\section{Introduction}

Phenological studies deal with recurrent biological events particular to one or among several species, with the interference of biotic and abiotic factors (Lieth 1974). Moreover, they deal with seasonal regulation of events in life histories of organisms (Rathcke \& Lacey 1985). For plants, in particular, triggering of the phenophases may be related to variations in abiotic or biotic environment, and so a particular phenophase may be affected by selective pressures imposed by animals (van Schaik et al. 1993). Vegetative phenophases are dependent on climate seasonality, with strong variation in strategies for the production of new leaves. In the tropics, leaf sprouting may be continuous or seasonal, depending on limiting factors such as water availability (Wright \& van Schaik 1994). The occurrence of peaks of leaf sprouting in a year's time, low herbivore abundance at the dry season or asynchronic production of leaves may enable some leaves or flowers to escape from predation (Coley \& Barone 1996).

Gall inducers are plant parasites (Price 1984), which usually have strict, specific relationships either with their host plant or with organs of this plant. This specificity may be a consequence of limited movements during the larval phase, and to feeding sites, namely, the cells and tissues of the gall (Yamazaki \& Ohsaki 2006), which is eventually dependent on the oviposition site. Even though a preference for oviposition in young tissues was recorded (Rohfritsch 1992), some herbivores may induce galls either in young or mature leaves (Souza et al. 2000; Arduin \& Kraus 2001; Oliveira \& Isaias 2009). When gall induction occurs in young tissues, phenological synchronization between the host plant and the galling herbivore is necessary for the reproductive success of the latter (Yukawa 2000; Weis et al. 1988). Also, because of this requirement, there is a strong tendency among galling insects towards univoltinism (Weis et al. 1988). Considering the importance of this adjustment in the life cycles of the two organisms involved, the current study aimed to describe leaf gall phenology in two species of Aspidosperma over a year's time, relating the correspondence of initial gall phases to the availability of host plant tissues in responsive state. As evergreen plants are common in the Neotropics, we hypothesize that the availability of responsive tissues during the entire year is a major influence towards multivoltinism. In order to verify this statement, we analyzed two systems involving $A$. australe and an undescribed species of Pseudophacopteron (Phacopteronidae), and A. spruceanum and an unidentified species of Cecidomyiidae.

Due to the great abundance of galls in these two host plants, the gall systems have been the focus of

\footnotetext{
Universidade Federal de Minas Gerais, Instituto de Ciências Biológicas, Departamento de Botânica, Belo Horizonte, MG, Brasil

2 Universidade Federal de Goiás, Instituto de Ciências Biológicas, Departamento de Biologia Geral, Goiânia, Brasil

3 Corresponding author: lemos@icb.ufmg.br
} 
morphological, ultrastructural, chemical and histochemical studies. The anatomical aspects of the galls of $A$. australe were presented by Christiano (2002), while Formiga et al. (2009) related the structural aspects of the galls of $A$. spruceanum to the variation in phenolic contents over a year's time. Oliveira and Isaias (2010) and Oliveira et al. (2010) related the ultrastructural and histochemical aspects of both galls to tissue nutritional metabolism. Therefore, the study of phenological events in galling insects and hostplant life cycles should contribute to the knowledge of these woody Apocynaceae species, and also generate complete models involving gall systems in the Neotropics.

\section{Materials and methods}

Phenological events of Aspidosperma australe and A. spruceanum were analyzed at Pampulha Campus of the Universidade Federal de

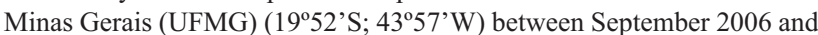
September 2007. Meteorological data were obtained from INMET at Belo Horizonte-Minas Gerais, Brazil, and clearly set a dry and a rainy season. During the study period, higher values of maximum temperature were recorded in March $\left(31.7^{\circ} \mathrm{C}\right)$, and lower values of minimum temperature in June and July $\left(15.7^{\circ} \mathrm{C}\right.$ and $9.3^{\circ} \mathrm{C}$, respectively) (Fig. 1). The wet season began in September 2006, with higher accumulated precipitation $(350 \mathrm{~mm})$ in January 2007. The dry season bega $n$ in May 2007, with no precipitation in June and August 2007.

For vegetative phenology, 10 individuals of each species were observed at 15-day intervals. Leaf sprouting, presence of mature (dark green) and senescent leaves (yellowish green), and leaf fall were evaluated by the visual percentage of areas occupied by the crown. The activity index (percentage of individuals in a specific phenophase), and the percentage of phenophase intensity, the Fournier index (Fournier 1974), were evaluated as described by Bencke \& Morellato (2002), using a scale of five categories (0-4 with intervals of 25\%). The results correspond to an average of the two evaluations per month.

Gall phenophases (induction, development, and senescence) were evaluated in 400 leaves per species. Each plant individual $(n=10)$ crown was divided into four quarters according to the cardinal points from where 40 leaves per individual were sampled, at each 15-day-interval observation. Induction phase was defined as the presence of distinct light green spots on leaf lamina (Fig. 2, 3), developmental phase was indicated by leaf lamina eruption (Fig. 4-7), and senescent phase by the presence of an aperture on the gall surface (Fig. 8, 9). For gall phenology, percentage of the three distinct phases was visually evaluated for each sample. All data were expressed as an average of the two evaluations per month.

Numerical data were submitted to Spearman correlation using Graph Pad Prisma software (Motulsky 1992-2009).

\section{Results}

Leaf galls were observed in both Aspidosperma species during the entire study period (Fig. 10, 11). For A. australe, levels of gall infestation fluctuated over the year, with $27 \%$ in September 2006. The highest percentage of galled leaves for this species was recorded in December 2006 (80\%), just after the peak of leaf sprouting which occurred in September 2006 (40\%). At this time of the year, A. australe had the highest activity index and percentage of phenology intensity. A high percentage of galled leaves occurred again in July 2007 (77\%), independently of new leaf production. After that time, the number of mature leaves reaches its maximum for all plant individuals (Fig. 12, 14). In A. spruceanum, gall infestation was superior to $50 \%$ all year long, reaching $75 \%$ in July 2007 (Fig. 11). Also, there is a continuous production of new leaves and the maintenance of a great proportion of mature leaves in the canopy (Fig. 13-15). The maximum percentage of galled leaves in $A$. spruceanum occurred nearly two months after leaf sprouting (July, 76\%), similarly to $A$. australe. In the present study, galls in developmental phase were recorded over the entire year (Fig. 18, 19).

The activity of the gall inducing Phacopteronidae was not recorded in A. australe in March, May, and from July to September 2007 (Fig. 18), exactly in the dry season (Fig. 1). For this insect, maximum induction activity was recorded in September 2006, concomitantly with the annual peak in the production of new leaves (Fig. 12). The Cecidomyiidae

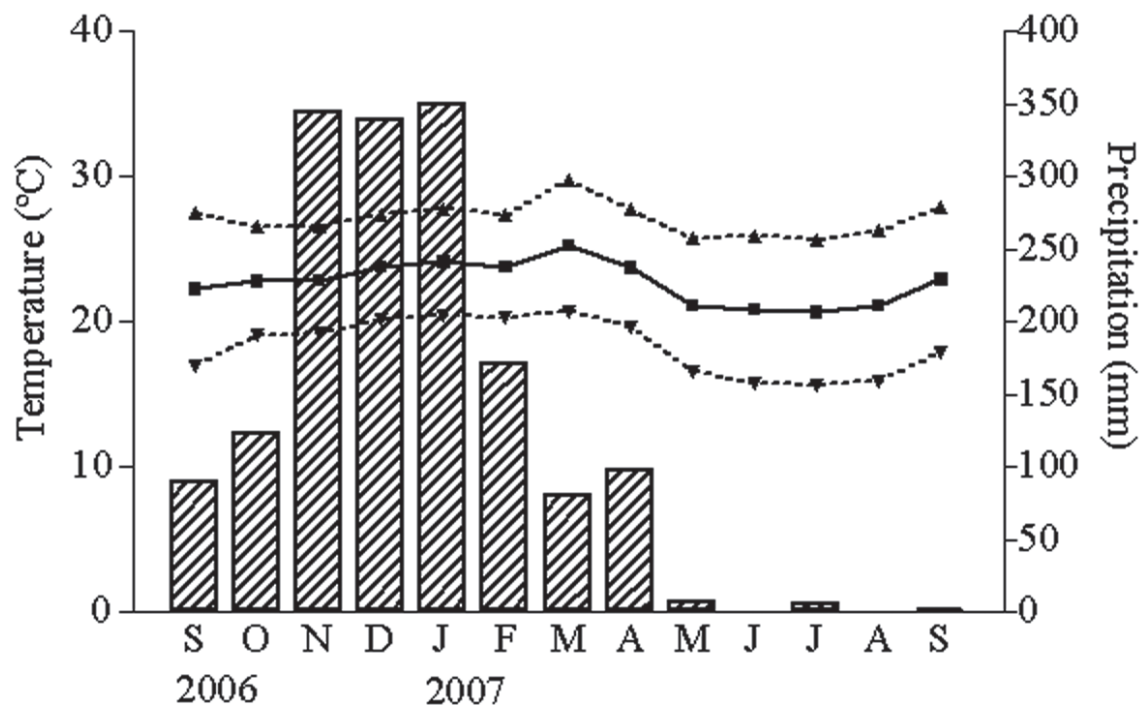

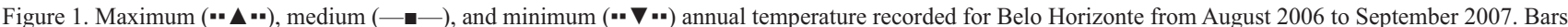
represent the monthly accumulated precipitation during the same period (Data from INMET, Belo Horizonte, Minas Gerais, Brazil). 

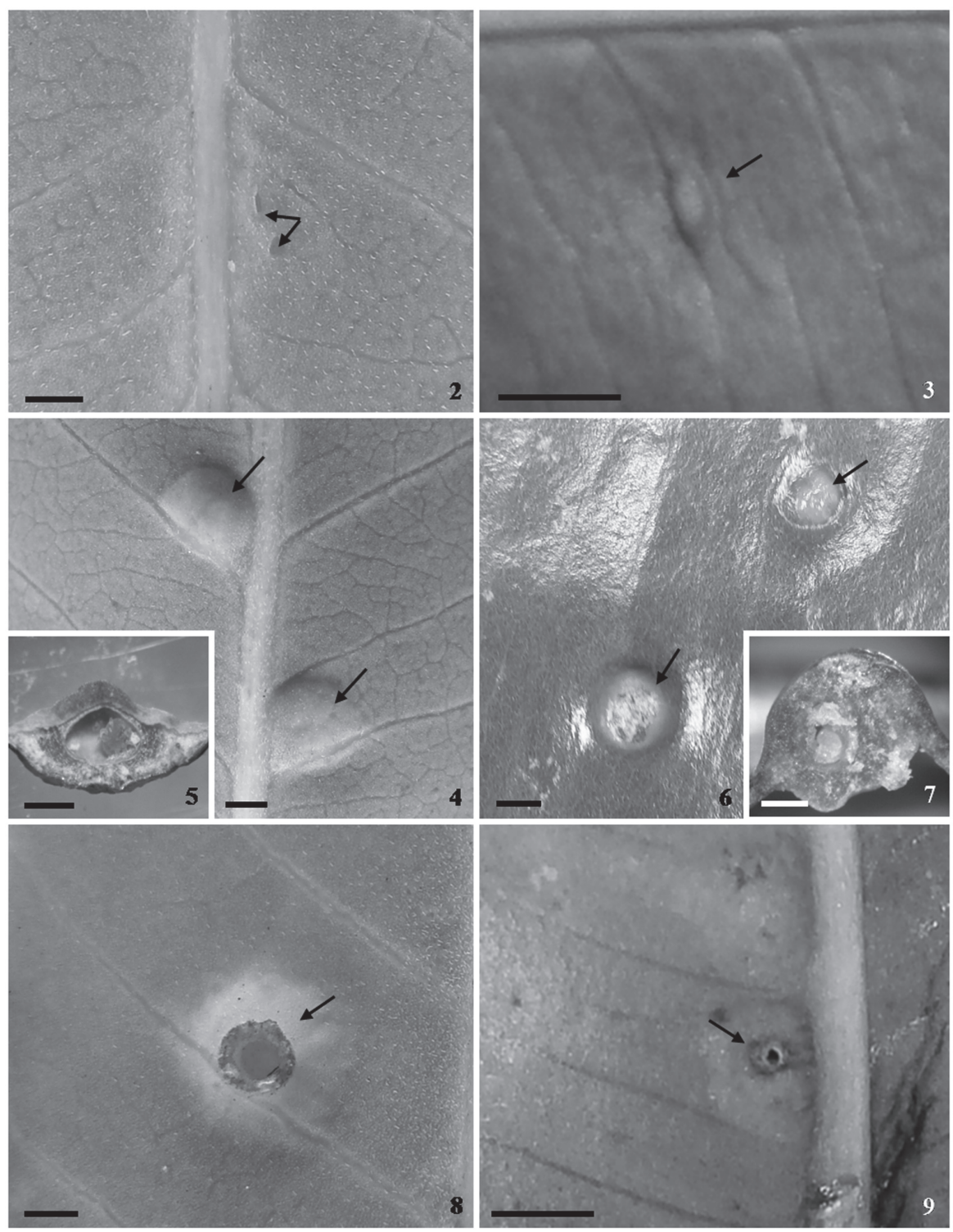

Figures 2-9. Developmental phases of galls induced by Phacopteronidae in Aspidosperma australe (2, 4, 5 and 8), and by Cecidomyiidae in Aspidosperma spruceanum (3, 6, 7 and 9). 2-3. Galls in induction phase. 4-7. Galls in developmental phase. 8-9. Senescent galls. The arrows indicate the corresponding developmental phase. Bars $=1 \mathrm{~mm}$.
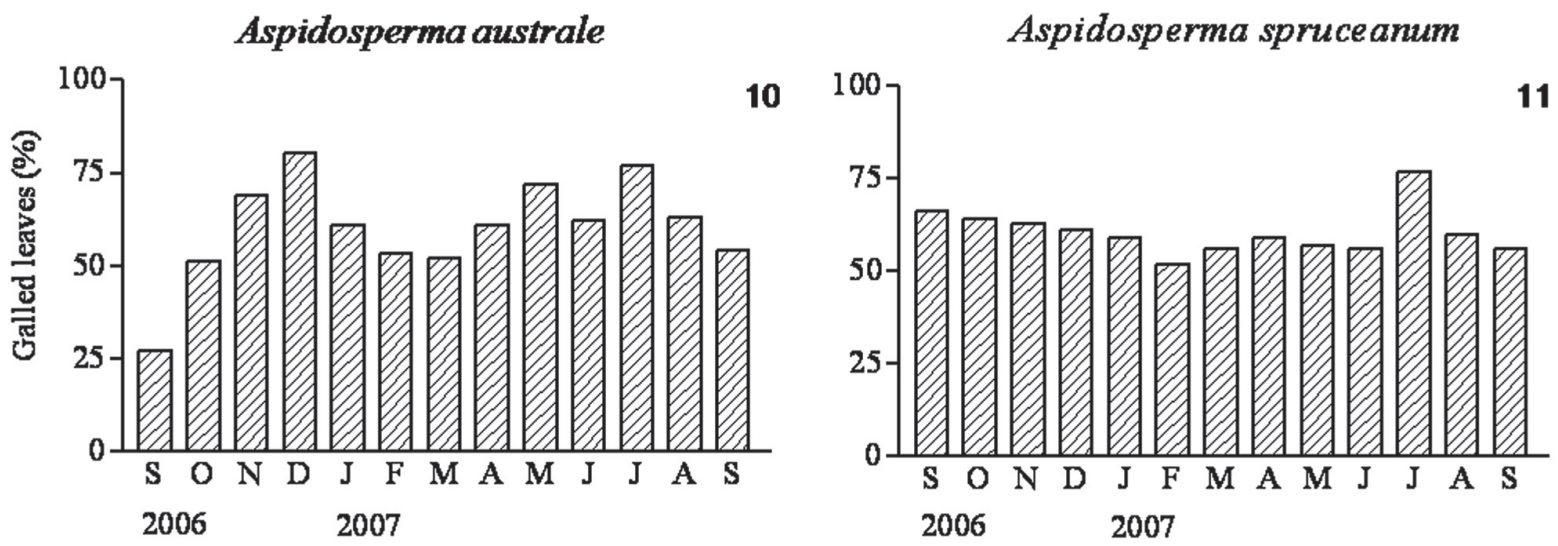

Figures 10-11. Percentage of galled leaves of Aspidosperma austral and A. spruceanum from September 2006 to September 2007. 

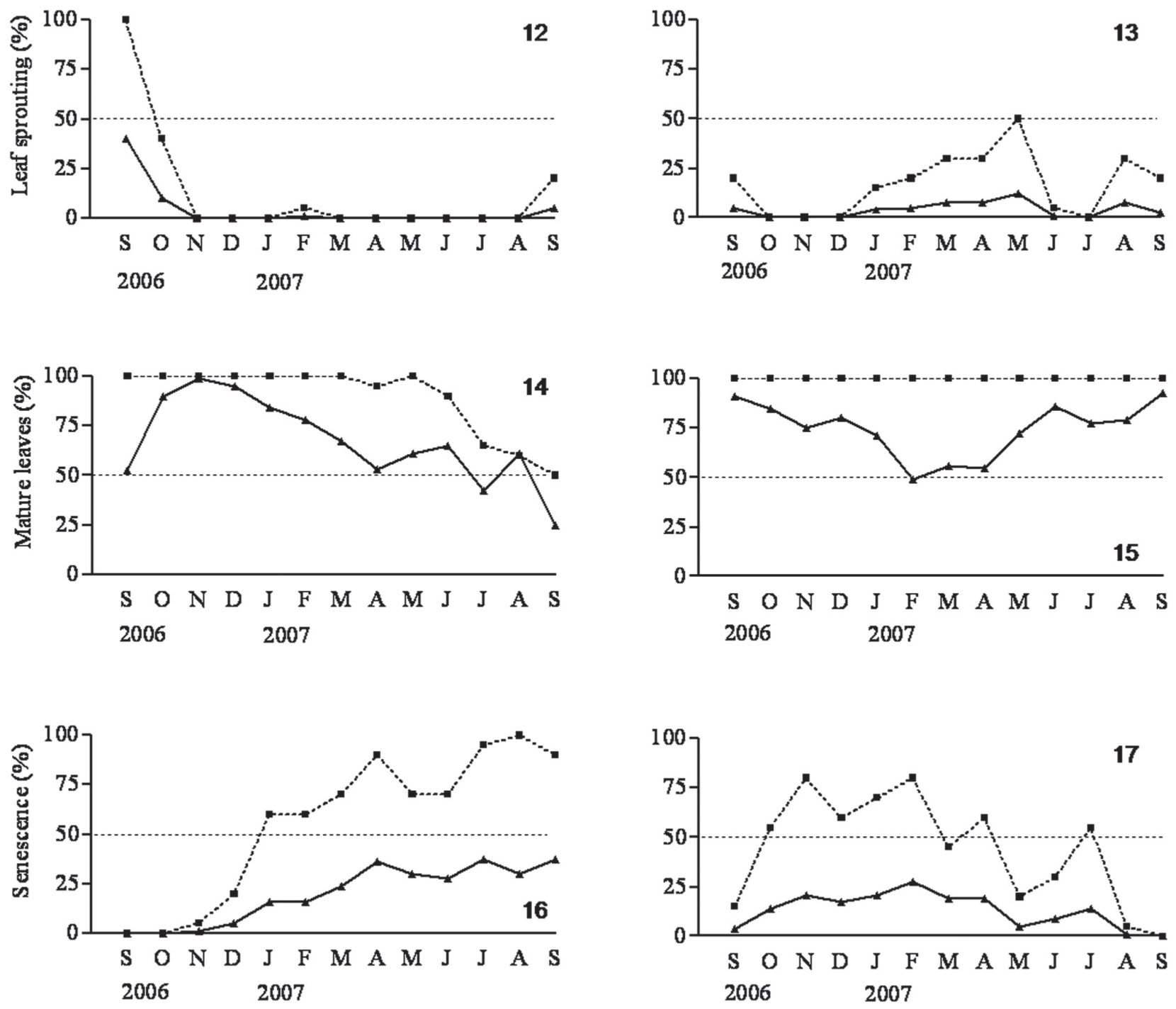

Figures 12-17. Phenological events in Aspidosperma australe and A. spruceanum according to the activity index (-- --$)$, and Fournier percentage of intensity (- - - ) $(\mathrm{n}=10) .12-13$. Leaf sprouting. 14-15. Mature leaves. 16-17. Senescence.

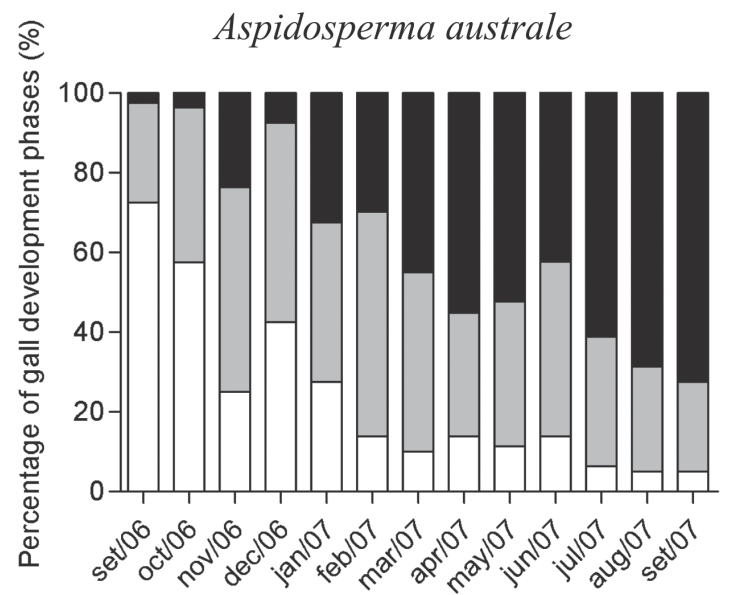

18 Aspidosperma spruceanum

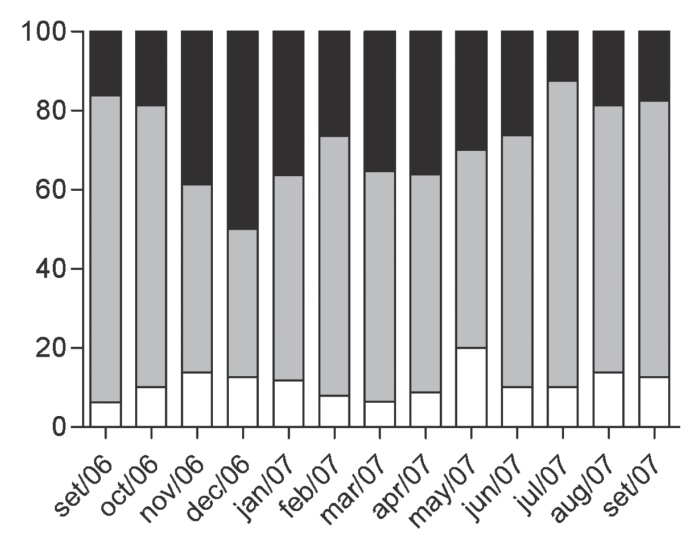

Figures 18-19. Percentage of galls in induction ( $\square$ ), development ( $\square$ ) and senescent ( $\mathbf{\square})$ phases ( $\mathrm{n}=10$ ) in Aspidosperma australe and A. spruceanum, from September 2006 to September 2007. 
induced galls in A. spruceanum during two periods, namely, in November-December 2006, and in April-May 2007. The former corresponded to the vegetative phenological phase when no leaf sprouting occurred (Fig. 13), and the latter coincided with the presence of many young leaves which had been permanently produced since January 2007 . The end of the gall cycles, i.e., gall senescence, was recorded over most of the year, except in September, October, and December, 2006 for A. australe (Fig. 18), while for A. spruceanum, the Cecidomyiidae ecloded from their galls all year long.

At the end of the rainy season, a low percentage of mature leaves on $A$. australe occurred, as a consequence of an increase in leaf senescence and abscission (Fig. 16). The lack of new leaf production from November 2006 to August 2007, as well as the slow senescence and abscission patterns, resulted in a reduction of total leaf area during the dry season $(32.5 \%)$. On the other hand, even though senescence and leaf fall have been recorded for $A$. spruceanum all year long (Fig. 17), continuous leaf sprouting (Fig. 13) compensates this lost, and did not result in significant reduction of total leaf area in the crown.

New leaf production was distinct between the two Aspidosperma host species. While A. australe had a definite period of leaf sprouting, A. spruceanum produced leaves almost continuously all year long, except in November and December 2006, and July 2007 (Fig. 12, 13). Nevertheless, both species had mature leaves over the entire year, which were optional oviposition sites for both galling herbivores. These herbivores had great reproductive success and are multivoltines, with the presence of adult forms (mature and senescent gall phases) and oviposition (induction gall phases) in almost all the months. In fact, the two Aspidosperma species had a high index of gall infestation all year long (Fig. 10,11), and gall induction occurred either in young or mature leaves (Fig. 12-15, 18, 19).

In the galls of $A$. australe, there was some correlation among plant phenophases and gall developmental phases. There was an increase in the percentage of gall induction in mature leaves $(r=0.562, p \leq 0.05)$, galls in development phase concomitantly with mature leaves $(\mathrm{r}=0.824, \mathrm{p} \leq$ 0.001 ), and gall eclosion occurred when senescent leaves were being shed $(\mathrm{r}=0.958, \mathrm{p} \leq 0.001$ and $\mathrm{r}=0.821$, $\mathrm{p}$ $\leq 0.001)$ (Tab. 1). Negative correlations were observed between gall induction and senescent leaves $(r=-0.868, p$ $\leq 0.001$ and $r=-0.783, p \leq 0.01)$, between gall development and leaf abscission $(r=-0.629, p \leq 0.05)$, and between gall eclosion and the percentage of mature leaves $(\mathrm{r}=-0.661, \mathrm{p} \leq$ 0.05). In A. spruceanum, there was no significant correlation among host plant phenophases and developmental phases of the gall, except between gall eclosion and leaf senescence $(\mathrm{r}=0.656, \mathrm{p} \leq 0.05)$. Even though gall senescence was recorded during most of the year, either for A. australe or $A$. spruceanum, this data should be analyzed with care because senescent galls should have been counted more than once, and consequently were overestimated.

\section{Discussion}

Generally, in the tropics, insect populations decrease in the dry season. New life cycles restart at the beginning of the rainy season, followed by a gradual increment until the next dry season (Coley \& Barone 1996; Bale et al. 2002). In the present study, galls in the developmental phase were recorded over the entire year, which apparently contradicts the general premise, but reinforces the strategy of using distinct reactive sites for gall induction all year long.

In $A$. australe, there was a low percentage of mature leaves from November 2006 to August 2007 as a consequence of no leafing, and senescence and abscission slowness, which also resulted in a reduction of total leaf area during the dry season. On the other hand, continuous leaf sprouting in A. spruceanum compensates leaf senescence, and did not result in significant reduction of total leaf area. These phenological events are generally related to seasonal variation in plant water status, mainly influenced by the availability of water in the soil, as well as by the capacity of water storage in plant tissues, as pointed out by Borchert (1994). Nevertheless, leaf area maintenance in the two species studied, even in the dry season, indicated that, even after three months without precipitation, there was no significant limitation in the availability of water in the soil for these plants, similarly to the observation of Lemos-Filho \& Mendonça-Filho (2000) for three woody legumes in the Atlantic Forest. Although maintenance of leaf area may also be related to an increase in transpiration during the dry season, A. australe or A. spruceanum presented a reduction in stomatal conductance at times of higher air vapor pressure deficit (Lemos-Filho et al. 2007). For the Phacopteronidae, maximum induction activity occurred during leaf sprouting, while for the Cecidomyiidae, induction activity occurred over the entire year. In these two species, the availability of induction sites distinctly influenced the behavior of galling herbivores.

Aspidosperma australe shows striking phenophases, and the gall inducing activity accomplishes the events of the plant life cycle. The correlation between the induction of galls and the presence of mature leaves all year long demonstrated the availability of reactive sites for gall inducing. On the other hand, A. spruceanum presented leaf sprouting and mature leaves all year long, with no expressive, distinct phenophases. The negative correlation between the induction phase of the galls and leaf senescence and abscission denoted the necessity of the galling insect for reactive sites for oviposition, and nutrient and water availability for the development of the gall, corroborating the nutritional hypothesis (Weiss et al. 1988; Bronner 1992).

In the current study, both species of galling herbivores are multivoltines, which seems to be common at subtropical and tropical latitudes, where insect life cycles are often synchronized with host plant phenology (Burckhardt 2005). Even with significant leaf fall, mature leaf maintenance all year long made it possible to classify these species as evergreen, according to the proposal of Duff et al. (1997). 
Table 1. Spearman correlation among plant phenophases (leaf sprouting, mature and senescent leaves, and leaf abscission) and phases of gall development (induction, development and post-eclosion) in Aspidosperma australe and $A$, spruceanum, $\mathrm{R}$-values with an asterisk are significant at * $\mathrm{P} \leq 0,05 ; * * \mathrm{P} \leq 0,01 ; * * * \mathrm{P} \leq 0,001$.

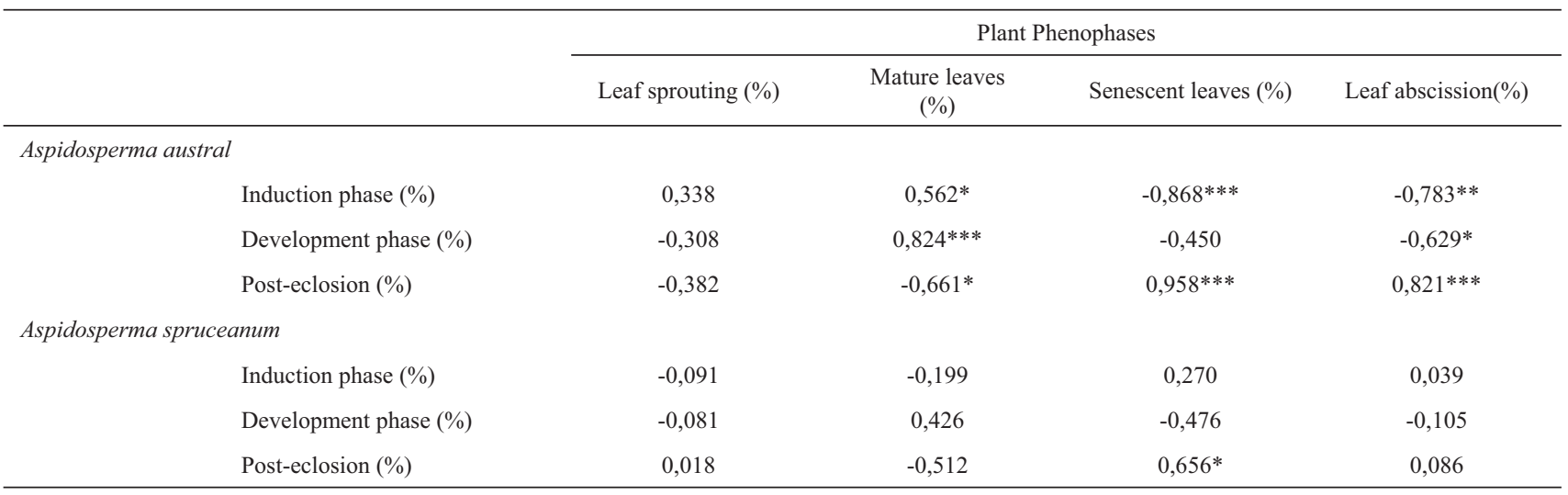

On the other hand, in temperate and subarctic or subantarctic regions many species are univoltine with winter dormancy or inactivity. Overwintering occurs as egg, larva, or adult depending on the species.

In both Aspidosperma species, gall induction occurred either in young or mature leaves, a behavior previously recorded for tropical galls of Ficus microcarpa induced by Gynaikothrips ficorum (Souza et al. 2000), for unidentified species of galling herbivores in Baccharis concina, $B$. dracunculifolia (Arduin \& Kraus 2001), and in Copaifera lansgdorffii (Oliveira \& Isaias 2009). Even though galls should generally be induced in young tissues (Rohfritsch 1992), the galling inducers of Aspidosperma species trigger galling stimuli in differentiated cells. This behavior generates a high specificity to the host plants in situations where no responsive tissues are available; the galling herbivores may use alternative inducing sites, the mature tissues, as observed by Oliveira \& Isaias (2009). Due to the short duration of the adult phase of galling insects, the females that do not locate susceptible structures must deposit their eggs at nonpreferential sites (Weis et al. 1988; Eliason \& Potter 2000).

The synchronization of the herbivore life cycle with phenological phases of the host plant determines the quality and quantity of feeding resources, which are critical for galling insects (Yukawa 2000). As pointed out by Mendonça Jr. (2001), the most important step in the life history of galling insects is the discovery of adequate reactive sites for gall induction. In $A$. australe and $A$. spruceanum, the analyses of vegetative phenological phases revealed a continuous availability of responsive tissues. The responsiveness of either mature or immature leaf tissues was evidenced by signals of developing galls during the one-year period analyzed. It was evident that the galling herbivores of these two Aspidosperma species might use mature tissues as alternative oviposition sites. These facts explained the high level of infestation during the year, and denoted that there was a perfect adjustment between the resources of Aspidosperma host plants and the life cycles of their associated herbivores, which is responsible for the multivoltinism established in these two systems.

\section{Acknowledgements}

The authors are gratefully thankful to G.W. Fernandes and D. Burckhardt for the insect identification, and FAPEMIG for financial support (Proc. CRA-465/04). J.P. Lemos-Filho and Rosy M. S. Isaias also thank CNPq.

\section{References}

Arduin, M. \& Kraus, J.E. 2001. Anatomia de galhas de ambrosia em folhas de Baccharis conccina e Baccharis dracunculifolia (Asteraceae). Revista Brasileira de Botânica 24: 63-72.

Bale, J.S.; Marsters, G.J.; Hodkinson, I.D.; Awmack, C.; Bezemer, M.; Brown, V.; Butterfield, J.; Buse, A.; Coulson, J.C.; Farrar, J.; Good, J.E.G.; Harrington, R.; Hartley, S.; Jones, T.H.; Lindroth, R.L.; Press, M.C.; Symrnioudis, I.; Watt, A.D. \& Writtaker, J.B. 2002. Herbivory in global climate change research: direct effects of rising temperature on insect herbivores. Global Change Biology 8: 1-16Bencke, C.S.C. \& Morellato, P.C. 2002. Comparação de dois métodos de avaliação da fenologia de plantas, sua interpretação e representação. Revista Brasileira de Botânica 25: 269-275.

Borchert, R. 1994. Soil and stem water storage determine phenology and distribution of tropical dry forest trees. Ecology 75: 1437-1449.

Bronner, R. 1992. The role of nutritive cells in the nutrition of cynipids and cecidomyiids. Pp. 118-140. In: Shorthouse, J.D. \& Rohfritsch, O. (eds.). Biology of insect induced galls. Oxford University Press, New York.

Burckhardt, D. 2005. Biology, ecology, and evolution of gall-inducing Psyllids (Hemiptera: Psylloidea). Pp. 243-258. In: Shaefer, C.W.\& Withers, T.M. (eds.). Biology, ecology, and evolution of gall-inducing arthropods. Enfield, Science Publishers.

Christiano, J.C.S. 2000. Respostas cecidogênicas no modelo Aspidosperma australe (Apocynaceae) - Pseudophacopteron sp. (Homoptera: Phacopteronidae). Dissertação do Mestrado. Universidade de São Paulo, São Paulo.

Coley, P.D. \& Barone, J.A. 1996. Herbivory and plant defenses in tropical forests. Annual Review of Ecology and Systematics 27: 305-335.

Duff, G.A.; Myers, B.A.; Willians, R.J.; Eamus, D.; O ' Grady, A. \& Fordyce, I.R. 1997. Seasonal patterns in soil moisture, vapor pressure deficit, tree canopy cover and pre-dawn water potential in a Northern Australia savannah. Australian Journal of Botany 45: 211-224.

Eliason, E.A. \& Potter, D.A. 2000. Budburst phenology, plant vigor, and host genotype effects on the leaf-galling generation in Callirhytis cornigera (Hymenoptera: Cynipidae) on pin oak. Environmental Entomology 29: 1999-1207. 
Formiga, A.T.; Gonçalves, S.J.M.R.; Soares, G.L.G. \& Isaias, R.M.S. 2009. Relação entre o teor de fenóis totais e o cilco das galhas de Cecidomyiidae em Aspidosperma spruceanum Müll. Arg. (Apocynaceae). Acta Botanica Brasilica 23: 93-99.

Fournier, L.A. 1974. Um método cuantitativo para la medición de características fenológicas em árbores. Turrialba 24: 422-423.

Lemos-Filho, J.P. \& Mendonça-Filho, C.V. 2000. Seasonal changes in the water status of three woody legumes from the Atlantic forest, Caratinga, Brazil. Journal of Tropical Ecology 16: 21-32.

Lemos-Filho, J.P.; Christiano, J.C.S. \& Isaias, R.M.S. 2007. Efeitos da infestação de insetos galhadores na condutância e taxa relativa de transporte de elétrons em folhas de Aspidosperma australe Müell. Arg. e de A. spruceanum Benth. ex Müell. Revista Brasileira de Biociências 5: 1152-1154

Lieth, H. 1974. Purpose of a phenology book. Pp. 3-19. In: Lieth, H. (ed.). Phenology and seasonality modeling. Berlin, Springer.

Mendonça Jr., M.S. 2001. Galling insect diversity patterns: the resource synchronization hypothesis. Oikos 95: 171-176.

Motulsky, H. 1992-2009. Analyzing data with Graph Pad Prism software. San Diego. GraphPad Software Inc.

Oliveira, D.C. \& Isaias, R.M.S. 2009. Influence of leaflet age in anatomy and possible adaptive values of the midrib gall of Copaifera langsdorffii (Fabaceae: Caesalpinioideae). Revista de Biologia Tropical 57: 293-302.

Oliveira, D.C. \& Isaias, R.M.S. 2010. Cytological and histochemical gradients induced by a sucking insect in galls of Aspidosperma australe Arg. Muell (Apocynaceae). Plant Science 178: 350-358.
Oliveira D.C.; Magalhães, T.A.; Carneiro, R.G.S.; Alvim, M.N. \& Isaias, R.M.S. 2010. Do Cecidomyiidae galls of Aspidosperma spruceanum (Apocynaceae) fit the pre-established cytological and histochemical patterns? Protoplasma 242: 81-93.

Price, P.W. 1984. Insect ecology. New York, Academic Press.

Rathcke, B. \& Lacey, E.P. 1985. Phenological patterns of terrestrial plants. Annual Review of Ecology and Systematics 16: 179-214.

Rohfritsch, O. 1992. Patterns in gall development. Pp. 60-86. In: Shorthouse, J.D. \& Rohfritsch, O. (eds.). Biology of insect induced galls. New York, Oxford University Press.

Souza, S.C.P.M.; Kraus, J.E.; Isaias, R.M.S. \& Neves, L.J. 2000. Anatomical and ultrastructural aspects of leaf galls in Ficus microcarpa L.F. (Moraceae) induced by Gynaikothrips ficorum Marchal (Thysanoptera). Acta Botanica Brasilica 14: 57-69.

van Schaik, C.P.; Terbough, J.W. \& Wright, S.J. 1993. The phenology of tropical forests: adaptive significance and consequences for primary consumers. Annual Review of Ecology and Systematics 24: 353-377.

Weis, A.E.; Walton, R. \& Crego, C.L. 1988. Reactive plant tissue sites and the population biology of gall makers. Annual Review of Entomology 33: 467-486.

Wright, S.J. \& van Schaik, C.P. 1994. Light and the phenology of tropical trees. American Naturalist 143: 102-199.

Yamazaki, K. \& Ohsaki, N. 2006. Willow leaf traits affecting host use by lead-gall-forming sawfly. Population Ecology 48: 363-371.

Yukawa, J. 2000. Synchronization of gallers with host plant phenology. Population Ecology 42: 105-113. 